\title{
APPLICABILITY OF THE CARMACK AMENDMENT TO IMPORT SHIPMENTS DAMAGED WHILE MOVING IN INTERSTATE COMMERCE:
}

WHEN connecting carrier lines are used to transport goods within the United States, the shipper normally contracts with the initial carrier for through transportation to the ultimate destination, and this carrier, in turn, undertakes to arrange for transportation along succeeding lines. 1 Prior to 1906, when Congress enacted the Carmack amendment ${ }^{2}$ to the Interstate Commerce Act, it was uncertain whether, in the absence of a special contract, an initial carrier receiving property for through shipment was liable for damage occurring throughout the entire shipment or whether its liability ceased upon delivery to a connecting carrier. ${ }^{3}$ There was general agreement, however, that by a stipulation in the bill of lading a carrier could limit its liability to damage occurring on its own line. Since these stipulations were the common practice, the owner of property shipped over different carriers had the difficult burden of placing the responsibility for any damage. ${ }^{5}$ Frequently unable to do this, he was left without adequate remedy.

The Carmack amendment changed this situation ${ }^{\circ}$ by providing that the

* Reider v. Thompson, 176 F.2d 13 (5th Cir. 1949); Strachman v. Palmer, 82 F. Supp. 161 (D. Miass. 1949).

1. To facilitate contractual agreements for through shipment, common carricrs cooperate in publishing through routes and joint rates for transportation between different points in the United States. As a result, though independently managed, connecting carriers have become, in effect, part of a single system. See Atlantic Coast Line RR. $v$. Riverside Mills, 219 U.S. 186, 198 (1911).

-2. 34 STAT. 593 (1906), as amended, 49 U.S.C. $\$ \S 20(11)$ and (12) (1946).

3. Some American jurisdictions adopted the English rule that mere receipt of property for transportation beyond the line of the receiving carrier, without any qualifying agreement, justified an inference of an agreement for through transportation and an assumption of full carrier liability over the entire route. However, the majority American rule and the rule adopted by federal courts limited a carrier's liability to damage occurring on its own line unless the carrier specifically contracted to carry over the whole route. For the continuance of the shipment beyond its own line the carrier was liable only as a forwarder. See Atlantic Coast Line R.R v. Riverside Afills, 219 U.S. $186,197-8$ (1911).

4. See Southern Pac. Co. v. Interstate Commerce Commission, 200 U.S. 536, 554 (1905).

5. The burden so imposed on the owner of a through shipment was multiple. He not only had to determine the proper party to sue and to obtain evidence largely in the hands of the participating carriers, but he also had to seek recovery under diverse state regulations and often had to travel great distances to institute a suit. As a result he vas compelled in many instances to agree to whatever settlement was proposed. Ronerss, Federal Liabilities of Carriers 685-6 (2d ed. 1929).

6. The purpose of the Carmack amendment was explained by Senator William Richardson of Alabama in reporting the bill out of subcommittee. See 40 Coric. REC. 9580 (1906).

The Carmack amendment did not deprive the owner of property shipped under a 
first common carrier accepting goods for interstate shipment was required to issue a through bill of lading to the final destination. The initial carrier was made liable to the owner of the goods or the lawful holder of the bill of lading for damage caused by it or by any other connecting carrier. ${ }^{7}$ It was left to the participating carriers to settle their ultimate liability among themselves. ${ }^{8}$ The first Cummins amendment subsequently extended the territorial application of the Carmack amendment to cover damage occurring on a through export shipment to a point in an adjacent foreign country. And later, the Carmack amendment was further enlarged to make the liability of the delivering or terminal carrier in an interstate shipment coextensive with that of the initial carrier. ${ }^{10}$

There is no reference in the Carmack amendment to foreign shipments other than exports to an adjacent foreign country. The bulk of foreign shipments, however, are exports to non-adjacent countries and imports from both adjacent and non-adjacent countries. In regard to these shipments the amendment is silent. Two recent decisions, Reider $v$. Thompson ${ }^{11}$ and Strachman v. Palmer, ${ }^{22}$ have refused to extend the amendment to cover im-

through bill of lading of his common-law right of action against the carricr primarily responsible for damage. See Chicago \& N.W. Ry. v. Whitnack Produce Co., 258 U.S. 369 (1922).

7. By the Carmack amendment the same liability of the initial carrier upon its own line is imposed on it as to any loss or damage on the lines of connecting carriers. Proof of delivery to it in good condition and of defective delivery to the consignce at the final destination raises a presumption of negligence creating liability for loss or damage caused thereby. It is then up to the initial carrier to rebut this presumption by showing that the loss or damage occurred under a recognized exception to its liability, e.g., due to an act of God, of the public authorities or of a public enemy, due to contributory negligence, or due to the inherent nature of the goods. See Galveston, H. \& S.A. Ry. v. Wallace, 223 U.S. 481, 492 (1912).

8. The initial carrier was found to have far greater facilities than the shipper for locating responsibility for loss or damage to a through shipment. A proviso in the Carmack amendment granted the initial carrier the right to recover from the carrier on whose line the loss or damage was sustained the amount it paid to the owner of the property as a judgment or settlement, as well as any reasonable expense incurred in defending a court action. Roberts, FeDERAL LiabiLities of CARRIERs 686 (2d ed. 1929).

In the congressional debates prior to the enactment of the Carmack amendment it was predicted that a connecting carrier which was responsible for any damage would rarely contest its liability against the initial carrier. Reimbursement would be prompt because of the necessity for close cooperation if through route connections were to be maintained. 40 CONG. REC. 9580 (1906).

9. 38 Stat. 1196 (1915), as amended, 49 U.S.C. \$20(11) (1946). The legislative history of the Cummins amendment does not shed any light on the intent of Congress in extending the Carmack amendment to shipments to an adjacent foreign country, and the reasons inducing Congress to make this change are not clear. See Gulf, C. \& S. Ry. v. Hines, 239 S.W. 244, 249 (Tex. Civ. App. 1922).

10. 44 StAT. 1448 (1927), 49 U.S.C. $\$ 20(11)$ (1946) (Newton Amendment).

11. 176 F.2d 13 (5th Cir. 1949).

12. 82 F. Supp. 161 (D. Mass. 1949). 
${ }^{\circ}$ ports. By this interpretation, the initial and terminal domestic carriers are relieved from liability for damage occurring in the United States. ${ }^{13}$

The shipment involved in the Reider case originated in a non-adjacent country, Argentina, whereas the one in the Strachman case originated in an adjacent country, Canada, but the cases differed substantially only in the form in which the shipments were billed to their final destination. In the latter case the shipment moved into the United States under a through bill of lading, the device most commonly used in rail shipments to or from an adjacent country. In the Reider case, as is the normal practice with foreign shipments involving carriage by sea, the obligations for foreign and domestic transport were clearly separated.14 This shipment originated under an ocean bill of lading calling for discharge at a port in the United States. Upon arrival it was delivered to a domestic carrier which issued a new bill of lading for interstate carriage by its own and connecting lines. In both cases it was alleged in the pleadings, and in the Strachman case it was found as a fact, ${ }^{15}$ that damage occurred during the domestic movement.

The holdings in the Reider and Strachman cases make the Carmack amendment narrower in scope than the Interstate Commerce Act of which it is a part. This latter act expressly covers all foreign shipments to the extent of their movement within the United States. ${ }^{16}$ Furthermore, a domestic

13. Congress, of course, had no authority to impose the statutory liability of the Carmack amendment on a foreign carrier. Southern Pac. Ry. of MLe:. v. Gonzalez, 48 Ariz. 260, 61 P.2d 377 (1936). However, it could have imposed liability for the entire foreign shipment on the initial or terminal domestic carrier, as it did in the Cummins amendment. Or, it could have specifically provided that in the case of an import shipment the first domestic carrier should be the initial carrier and in the case of an export shipment the final domestic carrier should be the terminal carrier for purposes of the Carmack amendment. Id. at 279,61 P.2d at 385. But query whether the provisions of the Carmack amendment were not already sufficiently broad to include all interstate movements. See p. 572 infra.

14. It is the general practice of shippers to consider these obligations separate even when a through import bill of lading is used. Communication to the YaLE Law Jounstar from Samuel Shapiro \& Co., Baltimore, Aid., October 21, 1949, in Yale Law Library. The ICC has indicated that it considers a through export bill for rail and ocean carriage as an instrument combining, for the convenience of the shipger, the separate obligations of the rail carriers to the American port and of the ocean carrier beyond. In Alatter of Bills of Lading, 52 I.C.C. 671, 730 (1919).

15. 82 F. Supp. 161,163 (D. MIass. 1949).

16. Section $I(1)$ of the Interstate Commerce Act provides that the Act shall apply to all common carriers engaged in transportation from one state to another or "from or to any place in the United States to or from a foreign country but only in so far as such transportation ... takes place within the United States." 41 STAт. 474 (1920), as amended, 49 U.S.C. \$1(1) (1946). This language was substituted by the Transportation Act of 1920 for the original language of the Commerce Act, which, in terms similar to those in the Carmack and Cummins amendments, provided that the Act was applicable to transportation between states and from any place in the United States to an adjacent foreign country. 24 Stat. 379 (1887), as amended, 36 Stat. 544 (1910). It has been suggested that, regardless of how the Carmack amendment may have been construed prior 
carrier receiving property at the border for interstate carriage comes within the precise wording of the Carmack amendment. ${ }^{17}$ The applicable words are: "Any common carrier [subject to the Interstate Commerce Act] receiving property for transportation from a point in one State . . . to a point in another State. . . This language does not anticipate the origin of a shipment before delivery to the first domestic carrier, nor does it except shipments which may have begun their travel in a foreign country. Nevertheless, the ICC has taken the position that there is a clear distinction in the Interstate Commerce Act between "foreign" and "interstate" shipments, that a foreign shipment moving in interstate commerce does not lose its essential character, and that accordingly foreign shipments, unless explicitly provided for, are not covered by the Carmack amendment. ${ }^{18}$

Perhaps the greatest impetus for this interpretation of congressional intent was an unwillingness to hold a domestic carrier responsible for damage occurring abroad and thus expose it to the hazard of having to recover over against a carrier operating outside the jurisdiction of the United States.10

to the enactment of the Transportation Act, by amending Section 1 in 1920 Congress intended that initial carrier liability should extend to the interstate movement of forcign shipments. See A. L. Wolfe \& Co. v. Mo. K. \& T. Ry. of Tex., 283 S.W. 250 (Tex. Civ. App. 1926) (adopting the contrary view).

17. Judge Sibley dissented in the 'Reider case because the "plain, unambiguous words of Section 20(11) [Carmack amendment] of the Interstate Commerce Act . . . uphold this suit." Reider v. Thompson, 176 F.2d 13, 16 (5th Cir. 1949). Judge Hutcheson, who concurred in the holding of the court, agreed that the plaintiff's case fell within the strict letter of the Carmack amendment but felt that this interpretation was contrary to tho legislative and judicial history of the amendment. Id. at 15.

18. In Matter of Bills of Lading, 52 I.C.C. 671, 729 (1919). This rtting, however, was made before the Transportation Act of 1920 amended the general scope of the Interstate Commerce Act as defined in Section 1. See note 16 supra.

There is only one state case specifically holding that the Carmack amendment is inapplicable to the interstate movement of an import shipment. Alwine v. Penn. R.R., 141 Pa. 558, 15 A.2d 507 (1940). Other courts, however, have reached a similar conclusion in regard to export shipments. Aldrich v. Atlantic Coast Line R.R., 104 S.C. 364, 89 S.E. 315 (1916) ; Houston E. \& W. Tex. Ry. v. Inman, 63 Tex. Civ. App. 556, 134 S.W. 275 (1911). These latter two cases were decided before the Cummins amendment, note 9 supra, which extended the Carmack amendment to exports to adjacent countries. The Aldrich case involved a shipment to an adjacent country (Mexico), while the shipment in the Inman case was to a non-adjacent country (Germany).

19. "A valid reason for the failure of the [Carmack] amendment to include foreign shipments within its provisions is not far to seek. The rule which forbids a common carrier to contract against liability for loss or damage caused by its connecting carrier $\ldots$ is an arbitrary one, and can only be upheld upon the grounds of public necessity; and it is entirely reasonable to conclude that Congress did not deem it wise to cxtend this rule so as to make the domestic carrier liable for loss occasioned by the negligence of a . . . foreign carrier, because the right of the domestic carrier to be reimbursed for any amount paid by it by reason of the default of a connecting carrier would be much more difficult of enforcement against a foreign carrier than it would if the shipment were merely interstate." Houston E. \& W. Tex. Ry. v. Inman, 63 Tex. Civ. App. 556, 559, 134 S.W. 275, 277 (1911); Aldrich v. Atlantic Coast Line R.R., 104 S.C. 364, 366, 89 
But a contrary result in the Reider and Strachman cases would not have this effect since both plaintiffs relied on the fact that there was delivery in good condition to the initial domestic carrier and receipt in a damaged condition at the final destination in the United States. ${ }^{20}$ These are the elements necessary for recovery under the Carmack amendment. ${ }^{21}$

Because an import shipment is not normally in the owner's hands immediately before delivery to the first domestic carrier, the burden on the claimant of establishing delivery in good condition might be difficult to sustain, but it would not necessarily be insurmountable. If a new bill of lading is issued in the United States, the Federal Bills of Lading Act will apply. ${ }^{22}$ Under this act there is a presumption that goods were delivered as recited in the bill of lading, ${ }^{23}$ and a "clean" bill would be proof, as against any visible damage, of delivery in good condition. No such presumption is made as to damage which the carrier could not have discovered by a reasonable inspection. ${ }^{24}$ But where, as in the Reider case, there is an interruption in transit at the border, the shipper, or his agents, and the first domestic carrier may have ample opportunity for inspection before the shipment begins its domestic movement. ${ }^{25}$

The Reider and Strachman decisions force the claimant seeking recovery for an import shipment damaged within the United States to establish a cause of action against the particular carrier causing the damage." This is

S.E. 315, 316 (1916) (both cases hold the Carmack amendment inapplieable to export shipments damaged within the United States and were cited by the ICC in ruling as to the applicability of the Carmack amendment to the interstate movement of foreign shipments, In Matter of Bills of Lading, 52 I.C.C. 671, 728 (1919)). See note 18 supro.

20. However, if the Carmack amendment is extended to the interstate movement of imports, there is a possibility that in a second suit brought by the initial or terminal domestic carrier to enforce its right of recovery, a different court may find that damage did not occur in the United States.

21. See note 7 supra.

22. The Federal Bills of Lading Act is applicable to any bill of lading issued by a domestic carrier covering an interstate movement. Federal Bills of Lading Act, \$1, 39 STAT. 538 (1916), 49 U.S.C. § 81 (1946) ; In Miatter of Bills of Lading, 52 I.C.C. 671, 727 (1919) (applicable to a bill of lading issued by a domestic carrier in a forcign shipment).

23. This presumption operates in favor of the owner of the goods in the case of a straight bill of lading and in favor of a bona fide purchaser of the bill, who relied on the description recited therein, in the case of an order bill of lading. Federal Bills of Lading Act, §22, 39 StAT. 542 (1916), as amended, 49 U.S.C. \$ 102 (1946).

24. Federal Bills of Lading Act, $\$ \$ 20,21,39$ STAT. 541 (1916), 49 U.S.C. $\$ \S 100,101$ (1946) ; ROBERTS, FEDERAL Liabil ITIES OF CARRIERS 763 et seq. (2d ed. 1929).

25. The shipment involved in the Reider decision was received at the port of entry by a forwarding company, acting as agent for the owner, and was delivered by this company to the first domestic carrier. Forwarding agents are commonly used unless the ocean carrier unloads directly at docks belonging to a receiving domestic railroad, in which case the ressel acts as agent for the owner in arranging for domestic carriage. In either case there is greater opportunity for inspection than if a through rail shipment, in the original cars, is merely switched at the border to the line of a succeeding carricr.

26. The situation would be no different in regard to an export shipment to a non- 
precisely what the Carmack amendment sought to avoid. Shipments to and from non-adjacent foreign countries are usually insured from warehouse to warehouse. ${ }^{27}$ However, in the Reider case insurance was limited to the marine part of the voyage. And shipments to and from adjacent countries are not so comprehensively insured, the owner of the goods having to bear the loss for many kinds of damage. ${ }^{28}$ But even if the insurance is comprehensive, the Reider and Strachman cases still have an important bearing on the rights of insurance companies as subrogees.

There is no reason why a foreign shipment may not be broken up into its foreign and domestic components so that the Carmack amendment may start to apply as soon as the goods are transferred to a domestic carrier. ${ }^{20}$ Where the obligations for foreign and domestic carriage are evidenced by separate bills of lading, the interstate movement of a foreign shipment may easily be considered a new shipment. ${ }^{30}$ But a foreign shipment should be no less divisible merely because it moves under a through bill of lading. ${ }^{31}$ Liability should attach as provided in the Carmack amendment as long as

adjacent country. But were recovery under the Carmack amendment allowed, the claimant in an export shipment, as distinguished from the claimant in an import shipment, might find it more difficult to establish delivery in a defective eondition at the final point in the United States than to establish delivery in good condition to the initial carrier.

27. Communication to the Yale Law Journal from Milton Snedeker Corp. New York, N. Y., dated Jan. 27, 1950, in Yale Law Library.

28. Ibid.

29. Foreign shipments are so divisible in the application of closely related provisions of the Interstate Commerce Act authorizing the ICC to prescribe through routes and joint through rates of transportation. 34 STAT. 589 (1906), as amended, 49 U.S.C. \$15(3) (1946) ; see News Syndicate Co. v. N.Y. Central R.R., 275 U.S. 179 (1927).

30. In the Reider case the only indication on the face of the original ocean bill of lading that the shipment was to move beyond the port of entry was a specification that notice of arrival be addressed to the owner at Boston. Upon delivery at the port, the obligations under the foreign bill were completely discharged, and before the shipment could move further, a new bill of lading had to be issued.

A new bill of lading issued by a connecting carrier in an interstate shipment does not render this carrier liable under the Carmack amendment as an initial carrier unless the second bill represents the initiation of a new undertaking. Mexican Light \& Power Co. v. Texas Mex. Ry., 331 U.S. 731 (1947). There is persuasive authority to the effect that, where all the obligations of a previous contract for shipment have been discharged, the carrier receiving the property under a subsequent contract is the initial carrier. Bracht v. San Antonio \& Ark. P. Ry., 254 U.S. 489 (1921) ; Baltimore \& O.R.R. v. Montgomery \& Co., 19 Ga. App. 29, 90 S.E. 740 (1916). If in spite of the underlying purpose of the Carmack amendment to establish unity of resfonsibility for an entirc domestic movement, Georgia, F. \& A.R.R. v. Blish Milling Co., 241 U.S. 190, 196 (1916), such a movement may be broken up in this fashion, there seems to be little reason why a foreign shipment, not covered by the amendment, may not be similarly treated.

31. The Carmack amendment expressly provides that liability will apply whether or not the bill of lading therein specified has been issued. Where no bill is issucd by the initial carrier, a shipper stands in the same position as if he were the holder of the bill of lading prescribed in the amendment. Standard Combed Thread Co. v. Penn. R.R., 88 N.J.L. 257, 95 At1. 1002 (1915). 